ББК 63.4

$$
\begin{gathered}
\text { Организация конференции и издание материалов проведены } \\
\text { при финансовой поддержке Российского фонда фундаментальных исследований, } \\
\text { проект № 19-09-20008 }
\end{gathered}
$$

Утверждено к печати Ученым советом ИИМК РАН

Редакционная коллегия тома II: А. В. Поляков, Е. С. Ткач (отв. редакторы), М. Т. Кашуба, Л. Б. Кирчо, Е. А. Черлёнок, В. Я. Стёганцева, А. И. Климушина

Рещензенты: д. и. н. Л. Б. Вишняцкий, д. и. н. А. А. Выборнов

Программный комитет конференции: академик РАН, д. и. н., проф. М. Б. Пиотровский (Государственный Эрмитаж, почетный председатель); д. и. н. В. А. Лапшин (ИИМК РАН, председатель); д. и. н. А. В. Головнёв (МАЭ РАН, сопредседатель); д. и. н. В. А. Дергачёв (Высшая антропологическая школа, Молдова, сопредседатель); д. и. н. И. Ф. Попова (ИВР РАН, сопредседатель); академик АН Республики Узбекистан, д. и. н., проф. Э. В. Ртвеладзе (сопредседатель); к. и. н. А. В. Поляков (ИИМК РАН, зам. председателя); к. и. н. В. А. Алёкшин (ИИМК РАН, зам. председателя); д. и. н. Ю. Е. Берёзкин (МАЭ РАН); Dr., Prof. Н. Бороффка

(Германский археологический институт, Германия); В. С. Бочкарёв (ИИМК РАН);

Dr. Э. Кайзер (Свободный университет Берлина, Германия); к. и. н. М. Т. Кашуба (ИИМК РАН); д. и. н. Л. Б. Кирчо (ИИМК РАН); к. и. н. А. В. Кияшко (Южный федеральный университет); к. и. н. П. Ф. Кузнецов (СГСПУ); к. и. н. Н. М. Малов (СНИГУ); к. и. н. В. П. Никоноров (ИИМК РАН); Ю. Ю. Пиотровский (Государственный Эрмитаж); д. и. н., проф. Д. Г. Савинов (Институт истории СПбГУ); к. и. н. В. Н. Седых (Институт истории СПбГУ); к. и. н. Н. Н. Скакун (ИИМК РАН); к. и. н. Н. Ф. Соловьёва (ИИМК РАН); к. и. н. А. И. Торгоев (Государственный Эрмитаж); к. и. н. Е. А. Черлёнок (Институт истории СПбГУ)

Организационный комитет конференции: к. и. н. А. В. Поляков (ИИМК РАН, председатель); к. и. н. В. А. Алёкшин (ИИМК РАН, зам. председателя); В. С. Бочкарёв (ИИМК РАН); к. и. н. М. Т. Кашуба (ИИМК РАН); д. и. н. Л. Б. Кирчо (ИИМК РАН);

А. И. Климушина (ИИМК РАН, отв. секретарь); к. и. н. В. П. Никоноров (ИИМК РАН); Ю. Ю. Пиотровский (Государственный Эрмитаж); В. Я. Стеганцева (ИИМК РАН); В. В. Терёхина (ИИМК РАН, МАЭ РАН, отв. секретарь); к. и. н. Е. С. Ткач (ИИМК РАН); И. Ж. Тутаева (Государственный Эрмитаж); к. и. н. Е. А. Черлёнок (Институт истории СПбГУ)

Древности Восточной Европы, Центральной Азии и Южной Сибири в контексте связей и взаимодействий в евразийском культурном пространстве (новые данные и концепции): Материалы Международной конференции, 18-22 ноября 2019 г., Санкт-Петербург. Т. ІІ. Связи, контакты и взаимодействия древних культур Северной Евразии и цивилизаций Востока в эпоху палеометалла (IV-I тыс. до н. э.). К 80-летию со дня рождения выдающегося археолога В. С. Бочкарёва. - СПб.: ИИМК РАН, Невская Типография, 2019. - 287 с.

ISBN 978-5-907053-35-9

DOI 10.31600/978-5-907053-35-9 


\title{
BRONZE CAULDRON FROM THE VILLAGE OF IVANOVSKOYE AND WOODEN WARE WITH BRONZE LUGS
}

\author{
Leonid S. Il'yukov \\ Southern Scientific Center of RAS, Rostov-on-Don, Russia
}

Keywords: Late Bronze Age, bronze riveted cauldron, wooden ware.

Bronze cauldrons from Eastern Europe having appeared in the Late Bronze Age evolved from riveted examples to cast ones. Two applied rings of the type hafted onto the rim of the Ivanovskoye cauldron were also fixed on the rims of wooden vessels and served as bases of their looped handles. On the Ivanovskoye example, a ring-shaped handle was attached from above to the butt of the ring. Their junction was cast in a mold and riveted to the rim of the cauldron. Possibly, the Ivanovskoye cauldron was an example transitory from the thin-walled riveted cauldrons with a handle to massive cast cauldrons with a ring-shaped vertical handle.

\section{МЕТАЛЛИЧЕСКИЕ И ГЛИНЯНЫЕ СОСУДЫ СРЕДНЕГО И ПОЗДНЕГО БРОНЗОВОГО - РАННЕГО ЖЕЛЕЗНОГО ВЕКОВ ЕВРАЗИИ: ВОЗМОЖНЫЕ ВЗАИМОСВЯЗИ}

Т. Сорочяну ${ }^{\star}$ Е. Сава ${ }^{\star *}$

* Германский археологический институт, Берлин, Германия; ${ }^{* *}$ Национальный музей истории Молдовы, Кичинёв, Молдова

DOI: $10.31600 / 978-5-907053-35-9-200-201$

Ключевые слова: Евразия, средний и поздний бронзовый век, металлические сосуды, клепаные котль, подражания в керамике.

Вопрос о копировании форм металлических сосудов по формам керамики занимает исследователей степных древностей уже более века. Вплоть до настоящего времени этот вопрос остается открытым. Сложность его решения заключается не только в количестве исходного материала, составляющего основу исследования, но и в отсутствии ответов на ряд других вопросов, например, являлась ли форма сосуда местной или заимствованной; существовали ли подобные формы сосудов в других материалах (дерево, кожа, камень). В целом дискуссия о том, в каком материале определенные формы сосудов появились раньше - в глине или металле - представляет лишь часть общей проблемы.

Тему имитации - металлические сосуды (в первую очередь, клепаные котлы) копировали глиняные образцы или vice versa, - в своих работах затронул целый ряд исследователей (Городцов, Макаренко, Кривцова-Гракова, Антоневич, Тереножкин, Бочкарев, Лесков, Отрощенко, Вегржанович, Демиденко, Бандривский, Ильюков, Гошко, Агапов, Отрощенко). В то же время следует отметить, что специальное исследование этой темы отсутствует.

На данном этапе мы проанализировали существующие мнения. Одним из основных вопросов является связь подражаний с изделиями разных культур: срубная, бережновскомаевская, андроновская, абашевская, синташтинская, потаповская, сабатиновская, белозерская, белогрудовская, а также более поздних. Мнения исследователей относительно подражаний зачастую являются противоположными: в одних случаях исходным материалом называют глину, в других - металл. Различаются и взгляды на конкретные находки, поскольку при их анализе, как правило, аналогии приводятся без учета комплексов; датировки также не всегда являются надежными. 
Согласно проведенному анализу материалов можно предложить некоторые предварительные выводы.

Клепаные котлы представляют собой продукт индивидуального производства, что не позволяет выявить общую схему первичности подражания между металлическими и глиняными сосудами. Известны лишь некоторые случаи, например в майкопской и андроновской культурах, когда можно установить определенную связь между глиняными и металлическими сосудами, но где так же сложно определить образец для имитации.

Элементы орнамента - гладкие валики; ряд овальных коротких, косо расположенных углублений по венчику; фриз из коротких вертикальных и зигзагообразных линий; плавно выполненные зигзагообразные полосы; заштрихованные треугольники, ромбы или орнамент типа «бегущей собаки»; пунктирные круги - редко создают надежную основу для сравнения заимствований и не дают оснований для выводов о первоочередности материала.

Невозможно говорить о единичном заимствовании из керамического или металлического набора форм, тем более что клепаные котлы «прошли» путь из Восточного Казахстана до границы Карпат почти за 1000 лет и пережили многочисленные морфологические изменения.

Индивидуальный типологический путь клепаных котлов прослеживается в ряде археологических культур, идет ли речь о случайном родстве форм или орнаментации. Влияния глиняных/металлических форм могли быть обоюдными, но ограниченными хронологически и типологически, так как производство клепаных котлов являлось индивидуальным и разнообразным, при этом могли иметь место опосредованные контакты между разными археологическими культурами, в которых имелись подобные керамические формы.

\title{
METAL AND CERAMIC VESSELS OF THE MIDDLE AND LATE BRONZE AGE - EARLY IRON AGE IN EURASIA: POSSIBLE INTERRELATIONS
}

\author{
Tudor Soroceanu ${ }^{\star}$, Eugen Sava ${ }^{* *}$ \\ ${ }^{*}$ German Archaeological Institute, Berlin, Germany; ${ }^{* *}$ The National Museum of the History \\ of Moldova, Chişinău, Moldova
}

Keywords: Middle and Late Bronze Age, metal vessels, forged cauldrons, imitations in pottery production, Eurasia.

The question of whether the shapes of metal vessels were copied from those of clay ones has been discussed by European scholars for over a century. However, no specialized work on this subject has been published. At the current stage of their research, the authors offer a preliminary systematization of existing views on this topic expressed in publications by a number of scholars. One of the principle questions is the connection of the imitated vessels with different archaeological cultures, such as the Timber Grave culture, Berezhnovsko-Mayevskaya, Andronovo, Abashevo, Sintashta, Potapovka, Sabatinovka, Belozersk, and Belogrudovka cultures, as well as with later cultural formations.

The researchers very often disagree concerning the interrelations of similar vessels made from different materials: while some scholars believe that clay vessels are prototypes for their metal analogues, others are of an opposite opinion. It is fairly possible that the interrelation between clay and metal can have been reciprocal. But this influence probably was limited in time and typology, while the evolution of forged cauldrons was rather specific and differed much. Therefore it could have been due only to indirect contacts with various cultural groups using similar forms of pottery. 